\title{
Explaining and Improving the Adoption of Voluntary Environmental Programs: A Social Cognition-Based View on Program Design, Implementation and Evaluation
}

\author{
Jasmin Kientzel (Corresponding author) \\ Maastricht Graduate School of Governance and United Nations University (UNU-MERIT) \\ Maastricht University, Netherlands \\ E-mail: jasmin.kientzel@maastrichtuniversity.nl
}

Gerjo Kok

Faculty of Psychology, Maastricht University, Netherlands

E-mail: g.kok@maastrichtuniversity.nl

Received: August 1, 2011

Accepted: September 5, $2011 \quad$ Published: December 1, 2011

doi:10.5539/jsd.v4n6p85

URL: http://dx.doi.org/10.5539/jsd.v4n6p85

\begin{abstract}
Voluntary Environmental Programs (VEPs) targeted at businesses are increasingly used as environmental and energy policy instruments. Numerous studies have focused on technological, economic, political, social and cultural factors that influence the success of a program. However, academic research and policy analysis have mostly focused on the impact and efficiency of programs while processes of VEP adoption and implementation that explain outcomes have been neglected to some extent. Recently, a growing body of research on environment and energy related behaviors has manifested. The study of factors influencing adoption behavior can contribute significantly to the understanding of VEP acceptance at the individual, organizational and societal level. In addition, limitations to voluntary program design and evaluation can be reduced by the application of behavioral and theory-based program planning. Social cognition models from social psychology and the technology acceptance literature show great potential to improve systematic understanding of VEP adoption behavior and enhance existing program design and evaluation methods. The present article adds to the existing academic literature and evaluation practice by reviewing social cognition-based models to further knowledge regarding VEP design, implementation and evaluation processes.
\end{abstract}

Keywords: VEPs, Social Cognition, Technology Adoption, Diffusion of Innovation, Program Evaluation and Design

\section{Introduction}

Voluntary environmental programs (VEP) have become a prominent instrument to fight climate change and reduce the impact of business activities on the natural environment. In many sectors, mandatory regulations for environmental protection have been unfeasible or lack support due to political and economic reasons. The importance of VEPs in the national and international policy mix has been stressed in a large number of publications (e.g. Gunningham \& Sinclair, 1999; Boerkey \& Leveque, 2000). VEPs are designed and implemented by numerous sponsors such as international organizations, national governmental agencies, industry or trade associations, and non-governmental organizations (NGOs). The predominant approach to developing environmental and energy programs in both regulatory and voluntary contexts has been grounded mainly in technical and economic considerations. Hence, technical issues and economic solutions have traditionally been high on the policy agenda dominating policy choice and program delivery (Lutzenhiser et al., 2009). The Physical-Technical-Economic Model (PTEM) has been the predominant paradigm for quite some time with choices and behavior considered to be influenced by information or economic incentives as suggested by rational actor theories. However, policy-making and resulting program design are hardly ever a neutral exercises and underlying behavioral assumptions shape program logics and Program Implementation Plans (PIP). Social scientists from various disciplines have become critical of the PTEM paradigm focusing on costs and rationality with program processes being treated as a black box. According to Lutzenhiser et al. (2009), the 
PTEM has been useful as a means of reaching the "low hanging fruits" in environmental and energy efficiency related issues but performs rather badly under more complex circumstances. While these issues are not specific to voluntary programs, the design and evaluation of these schemes suffer from the same limitations as other environmental initiatives. When designing and evaluating environmental programs, the analysis of social and psychological processes leading to adoption rates is still not perceived as being as useful as technical measurement or economic impact evaluation. Overall, the "human dimension" (Vine, 1994) of environmental program design and evaluation seems to be merely a secondary consideration in many environmental and energy-related schemes. This human dimension relates to the way decision-makers think about energy issues and the way they decide on investing in measures that reduce the environmental impact of their business activities (Vine, 1994).

As a result, a systematic focus on human factors can provide additional insights to some important questions such as (1) why and under which circumstances some professionals choose to integrate a VEP in their projects while others do not (2) how behavior-centered models can improve the design and evaluation of environmental programs and (3) how to improve VEP adoption rates if a specific program has found to be useful. The present paper aims to fill this gap by reviewing relevant models from the social sciences that can contribute to an improved understanding of VEP adoption decisions and behavior. The systematic use of theories to assess and improve VEP adoption will be stressed and limitations will be explored. Hereby we advance understanding of environmental initiatives and argue for cognition and theory-based design and evaluation of VEPs. We will mainly review literature in the management studies, social psychology, and technology acceptance research fields which have dealt with the role of social cognition in behavior change situations.

\section{Voluntary Environmental Programs (VEP): An Overview}

Business decisions have been traditionally analyzed in the economics, management and investment literature mostly based on the assumption that managers will consider investments only if these are financially advantageous. Since the study of VEPs has become a thriving field of investigation different disciplines have contributed a variety of approaches, theories and methods of analysis. Steelman and Rivera (2006) as well as Carmin et al. (2003) distinguish between several subcategories of Voluntary Environmental Programs:

As it can be seen in Table 1, VEPs include schemes as diverse as environmental management system certification (Darnall \& Edwards, 2006) to green labeling for products, eco-audit schemes, certifications for green buildings or Long-Term Agreements (LTAs) for energy efficiency etc. An increasing number of scientists have started to bring forward the importance of understanding and defining underlying behavioral assumptions in program design and evaluation. In this line of thinking, the effectiveness and success of voluntary schemes depends on their appeal to individuals and organizations and require acceptance from the decision-makers side (e.g. Nilsson \& Biel, 2008; Lutzenhiser et al., 2009). However, only a few VEPs have been designed with an integrated or associated behavioral or educational component. Voluntary behavior as a function of intentions, perceptions and actual control (Harrison, 1995), are frequently neglected in traditional voluntary environmental program design and evaluation. Even for those programs that do take it into account there is neither theoretical nor empirical evidence that the behavioral components match and target the underlying problematic behaviors which VEPs should ideally aim to change.

The lack of consideration of psychological and social factors in program design is partially due to the fact that identifying both factors to be changed and methods that work in specific contexts is a challenging task. As shown by Syme et al. (2000) in an extensive review on behavior change campaigns for household water conservation, behavior change is a complex and frequently misunderstood concept. Many failed programs, voluntary or not, are based on over simplistic models of decision-making, behavior and behavior change.

Social cognition aims "to understand and explain how the thoughts, feelings, and behavior of individuals are influenced by the actual, imagined, or implied presence of others" (Allport, 1985). Research conducted in this field analyzes individual decision-making and behavior as a function of social or cultural context determining in which ways people interpret information they receive from others or generate themselves (Sternberg, 1994). While cognitive processes' influences on decision-making and mental shortcuts (i.e. heuristics) also determine behavioral outcomes, the social cognition tradition focuses on the interaction between an individual and their respective context (Smith \& Semin, 2004). Hence, cognition is embedded in a social context and internal cognitive schemas are not sufficient to analyze and predict behavior. From this perspective, decisions and behavior will depend on an individual's goal, communication processes and social influence. These insights are valuable for the development, implementation and evaluation of voluntary environmental programs. 


\section{Environmental Program Design and Evaluation: An Application to VEPs}

The vast majority of VEPs is designed to achieve quantifiable outcomes and indicators, such as greenhouse gas (GHG) emission reduction and is grounded in the PTEM paradigm. Even though VEPs in their diversity are ideal to experiment with innovation in program design and evaluation, most organizations issuing them have not yet seized this opportunity.

Even though environmental policy analysis and program evaluation research established methods such as needs analysis or program theory analysis, behavior and social cognition-centered theories have been frequently left out of the picture. Even though PTEM can be seen as theory-based since it is building on rational actor theories, the designers of mainstream environmental programs have been few to explicitly state the use and limitations of the underlying assumptions in their schemes. In addition, the methods to induce behavior change are frequently limited within the PTEM paradigm focusing merely on providing incentives and information. Furthermore, there seems to be a lack of awareness that VEPs are essentially behavior change programs with environmental outcomes as results of human action (Vine, 1994). This issue links with a larger discussion in the design and evaluation literature: the debate on method-based and theory-oriented approaches (Weiss, 1997).Method-based approaches have been criticized heavily for creating a situation in which information on outcomes does not allow for informing analyses of impacts at higher levels or improve the understanding of programs (Stame, 2004). This "evaluation deficit" resulting from methods-based approaches neglecting the theory side has led in many cases to misperception of environmental programs and their meeting intended objectives (Stame, 2004). Such a "black box" problem (Astbury \& Leeuw, 2010) can be represented as follows:

Theory-based programs have been advocated bringing forward an agent-centered perspective (Pawson \& Tilley, 1997) and select variables explicitly assumed to achieve the program goals. Advantages of this approach are exposure of assumptions, comparability and hence the advancement of knowledge (Fitz-Gibbon \& Morris, 1996). According to Daamen et al. (2001), intervention and evaluation programs will be more successful if they take into account the specific characteristics of a receiver and can influence attitudes, beliefs and subsequently behavior. This principle should also apply to VEPs which have been less commonly designed as behavioral change programs even though they aim essentially to alter stakeholders' decisions and behaviors.

While theories from health planning have found their way in research and policies on pro-environmental behavior in private or household settings, programs targeted at environmental decisions in a professional setting are less common. Since the policy level does and should, however, take interest in promoting environmentally significant behavior from managers and firms, these frameworks can and have been applied to environmental program design and evaluation. There are two potential fields of application to program design: Either a program is (1) conceived by their sponsoring organization to fill a gap in the existing framework or a (2) program is designed to improve the adoption rate of a previous program. Both situations require a good understanding of both contextual and behavioral factors. Even if the behavioral antecedents and the reason for non-adoption are known, changing behavior can prove to be extremely challenging (Lippke \& Ziegelmann, 2008; Michie et al., 2008; Bartoholomew et al., 2011).While value and attitude change is desirable, infrastructures, incentives, institutions, abilities, knowledge and the difficulty of behavior will determine outcomes. Attitudinal factors, habits, routines, attitudinal factors but also contextual forces (interpersonal influences, community expectations, regulations, laws, advertising, costs and technological possibilities) need to be studied in context (Stern, 2004). Hence, broader frames of analysis are needed to study environmental decisions and behavior.

These broader analytical frames have been used traditionally in the health promotion field and offer a broader picture on the development of VEPs and contribute to select theories that could enhance their design and outcomes.

\section{Frameworks for Program Planning and Analysis: PRECEDE/PROCEED and Intervention Mapping}

In order to make VEPs more effective, their design, implementation and evaluation need to have a clear perspective on which behaviors need to be targeted and changed to make the program successful. Behavior change approaches assume that each person, be it a citizen or even a CEO has some level of choice and control over sustainability-related behaviors and actions. Policies, programs and regulations themselves cannot induce change if they are refused by the individuals or organizations they target. As mentioned above, the PRECEDE/PROCEED framework (Green \& Kreuter, 2005) and the Intervention Mapping approach (Bartholomew et al., 2006) are comprehensive frameworks which can be used to design an environmental program and constitute a solid basis for VEP evaluation. The models mentioned in previous sections can serve as a foundation for program design and induce behavioral change. Behavior change is required when a VEP is not adopted by firms it was targeted at or when an existing program has not yielded the expected results. In addition, 
there are theories that specifically target change in organizations are listed below.

A model that has been specifically developed to explain and promote environmentally significant behavior is the model proposed by Hines et al. (1987). They suggest that environmental education will contribute to improved pro-environmental behavior though (a) improved knowledge of environmental problems (2) the knowledge of potential strategies for action (3) the ability to apply these strategies (4) and the ownership of personality attributes. However, education by giving information alone has frequently led to poorly performing programs (Lutzenhiser et al., 2009). In addition, environmental education research has frequently been cited as having an impact on improved environmental behavior in private settings but has been less applied to professional contexts. One of the few behavior change programs for environmental professional practice is the Professional Practice for Sustainable Development initiative (PP4SD) in the United Kingdom. Most programs targeted at firms do not explicitly include behavioral components in their program implementation plans (PIPs). For a detailed review of behavior change models from the environmental education field see Heimlich and Hardoin (2008).

A well-known theory to analyze pro-environmental behavior change is Banduras' (1985) Social Cognitive Theory. According to this framework, individual decisions and behavior are a function of personal factors and their environment. Within Social Cognitive Theory, the main focus in on self-reflective, cognitive and self-regulatory processes (Bandura, 1985) as driving factors for change. Individual needs to perceive that they will be able to perform a given behavior and perceive to have an incentive to do so (Bandura, 1985). Behavioral change may be induced on several distinct levels, such as the individual, organizational and governmental level and targets the individual embedded in the organization rather than the organization as a whole. Behavior change theories are not only targeted at the individuals in organizations but also at organizations as a whole. Lewin (1951) developed his change theory based on habits and resulting resistance to change. According to Lewin (1951), habits prevail also in the case when circumstances change within groups. The focus in this model is a three step change process "unfreezing" the status quo moving the current perceptions and "refreezing" after a change has taken place. This is mainly used in change management, when clear targets have been set by a firms' management and employee resistance prevails. While the techniques evoked can be very beneficial it has usually been used within an organization when management has established an environmental goal and less when it comes to explaining more formal schemes such as VEP adoption and implementation which are frequently "contingent authority decisions" (Zaltman et al., 1973).

Selecting theories for specific behaviors and target populations can be a complex task since constructs are often present in several theories under different names (Bartholomew et al., 2011). In addition, in complex situations, several theoretical frameworks may need to be combined in order to understand adoption and non-adoption phenomena (Langlois \& Hallam, 2010). One framework which is useful as a guideline for both understanding program adoption and improving uptake is the PRECEDE/PROCEED model developed by Green and Kreuter (2005). While PRECEDE/PROCEED model has been developed for health promotion planning, it has been successfully applied to energy saving contexts (Egmond et al., 2005).In this framework, behavior is seen as a result of a large number of external and behavioral factors which need to be targeted in several stages. While the PRECEDE stage focuses on the analysis of the situation ex-ante or ex-post of a program including behavioral factors, context and policy instruments used, the PROCEED stage includes implementation as well as process, impact and outcome evaluations. Applied to VEP adoption, the process can be depicted as follows:

While developers of VEPs need to take into account a large number of factors, they also should base their programs on models that can influence the target actors' behaviors realistically. Although contextual factors are crucial in program development, implementation and evaluation, behavior-centered models analyzing the determinants of specific behaviors are crucial in Behavioral/Organizational Assessment (Phase 3) and Impact Evaluation (Phase 8).

The PRECEDE/PROCEED framework does not postulate which theories should be used for a specific VEP, but can be used as a guideline to select behavioral theories to explain the difference between adopters and non-adopters without neglecting contextual factors in which these behavioral factors are embedded in. Planning protocols and frameworks such as Intervention Mapping (Bartholomew et al., 2011) have emerged in order to discuss selection procedures for appropriate models and propose steps to create a structured theory-based program allowing for coherent evaluation based on known assumptions. Intervention Mapping (Bartholomew et al., 2011) is a protocol for theory and evidence-based program development which aims to provide guideline for selecting and applying theories to specific social problems in which behavior change is needed (Kok et al., 2004). In this process, Intervention Mapping consists of six major steps in which (1) the needs assessment is performed (2) program objectives are defined based on previous scientific analyses of the problems caused by specific behaviors (3) theories and strategies to change determinants of these behaviors are to be selected (4) program 
components are determined (5) program adoption and implementation as well as (6) process and effect evaluations are anticipated (Bartholomew et al., 2011). Even though the domain of management studies has traditionally focused on the issue of VEP adoption, program design and the selection of behavior-based theories have been neglected to some extent as the following section will show.

\section{Corporate Environmentalism: A Management Research Perspective}

The management literature on VEP adoption is vast and very diverse in nature. Most management-oriented studies are related in one way or the other to the concept of "corporate environmentalism". According to Banerjee (2002), corporate environmentalism can be defined as "the recognition and integration of environmental concerns into a firm's decision-making process". Previous research on the causes and consequences of corporate environmentalism has found significant variation in firm behavior (Darnall et al., 2010) and studies have identified market pressures, opportunities, government regulations and stakeholder pressure as potential causes for environmentally friendly firm practices (Banerjee, 2001).

According to Welch et al. (2000), "regulatory influence" is one of the major reasons why firm opt for VEP adoption. This theoretical perspective deems firm voluntarism to be a sign of commitment to environmental management with the intention of influencing the regulatory system. Moreover, the pressure of stakeholder such as customers, competitors, suppliers, investors and the community has frequently been cited as influencing the decision to adopt a VEP (Khanna et al., 2007). Likewise, the reduction of risks has been identified as a major factor in the business decision since the voluntary adoption of environmental schemes is a response to consumers interested in buying environmentally friendly produced goods (Arora \& Cason, 1996; Williams et al., 1993) and investors may favour environmentally proactive companies that can be successful in green markets (Khanna \& Damon, 1999; Khanna et al., 1998). Studies on firm characteristics have focused on industry affiliation, firm size, networks, team performances, decision structures (Khanna et al., 2007) while organizational studies have looked at organizational structure, capabilities, barriers, firm networks, or power relations (Hoffman, 2001).

While the management literature is relatively silent on VEP design, implementation and evaluation, a number of studies on organizational and individual level decisions in the management literature have heavily borrowed from models from sociology and social psychology. This provides evidence for many management scholars having recognized that "Corporate Environmentalism" as a concept treats the firm and the organization as a "black box" by emphasizing factors such as firm size, sector, financial performance or educational achievement on VEP adoption. There are a few examples for scholars having adapted social cognition models to the management literature.

Cordano and Frieze (2000) evaluated the Pollution Reduction Preferences of U.S. Environmental Managers and suggested that even though most environmental managers had positive attitudes towards pollution prevention, barriers such as too little incentives or communication issues have prevented them from pushing for a more environmentally stringent agenda. In the same line of reasoning, Martin-Pena (2010) evaluated managers' behavioral intentions towards environmental problems and suggests that environmental actions on the firm level are at least partly correlated with management's behavioral intentions. Additionally, Aragon-Correa et al. (2004) found a distinct link between executive discretion and corporate environmental commitment while Branzei et al. (2004) suggested a match between corporate environmental responses and individual values and responses in Chinese firms. A common theme of these studies is that knowledge alone will not by itself bring about behavioral change and other psychological processes need to be taken into account.

Even though management research has focused on models of decision-making such as the sensemaking literature (Weick, 1996), this field of research adopts a more micro-sociological perspective on decisions and behavior. Sensemaking studies have mainly focused on social group interactions and organizational dynamics and have not focused on in-depth mechanisms of cognitive processes and resulting behaviors (Weick et al., 2005). In this respect, for a more thorough understanding of decision and behavior, sensemaking has been mentioned merely as a starting point for exploring more specified models from the cognitive and social psychology literature. Sensemaking research has been applied to issues of environmental management (e.g. Sharma, 2000; Schlange, 2009). For the basis of behavior change, however, in-depth insights are needed to target specific factors in decision-making and behavioral processes. This is an issue that VEP designers, implementers and evaluators should keep in mind as well.

\section{Pro-Environmental Decision-Making and Behavior: Insights from Social Psychology}

Research grounded in social psychological theories has been crucial to opening the "black box" of the firm and analyze why and under which conditions certain barriers and drivers translate into pro-environmental behavior. The term "pro-environmental" is somewhat ambiguous, since it does not distinguish whether behavior is 
conscious, i.e. having environmental benefits as a goal or whether environmentally favorable outcomes are just a side effect of other considerations and decision processes. The literature generally encompasses both approaches to understanding behavior that reduces pollution, environmental damages and waste. Variables that have been identified in the social-psychology literature affecting environmental decisions and behavior in the overview presented in Table 2:

The factors in Table 2, however, will likely not be present in every environmental decision and affect all behavioral outcomes. As Stern (2004) suggested, conclusions about the causes of pro-environmental decisions and behaviors are unlikely to be generalizable across contexts and behaviors. Hence, the relative importance of determinants of behavior will depend on the type of behavior studied. Spatial and time dimension add to the complexity since responsibility for environmental action is perceived to be strongest at the local level where most people perceive environmental issues to be least concerning (Uzzell, 2007).

For that reason VEP adoption must be evaluated on a case-to-case basis to understand which factors are relevant since it is such a diverse category of schemes. According to Armitage and Conner (2000), social cognition models have been developed to account for differences in socio-demographic and social cognition variations in behavior. Two different categories are motivational and behavioral enactment models with the difference in the dependent variable: While motivational models frequently focus on behavioral intentions as the independent variable, behavioral enactment models aimed to explain the frequent difference between intention and action (Armitage \& Conner, 2000). Social cognition has been important not only in the psychology field but also found its way in the technology acceptance and adoption literature. Since a large number of behavior-centered models can explain individual differences in VEP adoption, the selection criteria in this article for including models as the basis of step 3 and 8 of the PRECEDE/PROCEED model is (1) whether they account for both external and internal factors that explain the decisions and behavior of individuals in a professional context and (2) include both predictors of behavior and actual behavior variables. Additionally, we focus in this paper on theories targeted at two dimensions, the micro- (individual) and meso-(group/organization) dimension. The selection presented here is bound to be limited since it will depend on the characteristics of a VEP which model(s) should be selected. We will present models for VEP program design, implementation and evaluation which include factors having been found to be important determinants of behavior and therefore crucial for behavior change including motivations, intentions, norms, knowledge, self-efficacy, awareness, attitudes, emotions, values and habits. These theoretical frameworks can be used by VEP planners and developers in order to analyze the determinants in existing behaviors to be targeted and changed in the implementation process.

\subsection{Pro-environmental decisions: Individual Decision Theories}

Studies on individual-level determinants of pro-environmental behavior are abundant in social psychology and related fields. However, the focus in most of these studies has been environmental and energy-related behavior in households while behavior in a professional role has been researched to a lesser extent. In most of the frameworks, a set of capabilities and barriers will influence whether an individual will engage in a specific behavior (Stern, 2000).

Stern and Dietz's (1994) Value-Belief-Norm (VBN) theory of environmentalism links norm-activation theory (Schwartz, 1977) and value theories (Schwartz, 1992). Within the model, values, a general set of beliefs, awareness of consequences, ascription of responsibility and norms lead to pro-environmental action (Stern, 2000). In the context of VEP adoption, managerial values, beliefs on environmental issues, awareness of responsibilities and the consequences as well as norms, routines or habits and contextual factors are important factors. There have been numerous applications of the VBN theory to design programs targeted at household-level conservation behavior supporting the models predictions (Widegren, 1998; Steg et al., 2005; Kaiser et al., 2005; Eriksson et al., 2008).

Similar to the VBN theory, the Attitude-Behavior- Context (ABC) Theory contributes to explaining environmentally significant behavior (Stern \& Oskamp 1987; Guagnano et al., 1995; Stern, 2000). In this framework, Behavior (B) is the product of attitudes (A) and contextual factors (C) with a behavior being performed depending on personal and contextual factors that influence individuals in their decision to take action at a given point in time (Stern, 2000). A prominent example is the A-B-C model developed by Guagnano et al. (1995) which postulates that behavior is determined jointly by an individual's structural environment and their general attitudes towards a given behavior (Guagnano et al., 1995). This theoretical framework assumes that individuals with positive attitudes towards a pro-environmental behavior will perform this behavior even when they face high external constraints. However, if external conditions are very facilitating, even those individuals with negative attitudes towards certain behavior will engage in this behavior (Jackson, 2005). According to 
Jackson (2005), the A-B-C model can be useful for policy-makers to improve facilitating conditions in environmental areas with low compliance. Since a number of VEPs have been suggested to work rather badly in reality, this model can be used as the basis to analyze behavioral determinants of VEPs adoption by professionals. Even though managers might have a pro-environmental attitude, contextual factors such as economic or policy related issues may prevent them from adopting more environmentally friendly business practices.

This aspect is closely linked to the concept of self-efficacy or perceived behavioral control. Developed by Bandura (1985), this concept has been used within the series of models developed by Fishbein and Ajzen (1980). Fishbein and Ajzen developed their Theory of Reasoned Action (TRA) model (1980) in order to evaluate the differences they found between attitude and behavior. The Theory of Reasoned Action postulates that an individual is determined by their intentions to carry out a certain action and that this intention will be a function of their attitudes towards a certain behavior and social norms surrounding the action (Ajzen \& Fishbein, 1980). In consequence, intention can be considered to be the best predictor of a given behavior and its antecedent. In an extension of the TRA, the Theory of Planned Behavior (Ajzen, 1991) states that behavior is in many cases not fully under control of an individual alone. Thus, the TPB builds on the TRA model and extends it with the concept of perceived behavioral control (Ajzen, 1985); intention is not only determined by subjective norms and attitudes but also by the control that individuals believe to have over their actions.

In order to predict intentions, the knowledge of underlying beliefs is crucial and necessary. Generally, the more favorable a certain attitude and subjective norm and the greater the perception of control individuals have regarding a given behavior, the more likely it is that a person's intention to perform a behavior will be stronger. In various settings, the TPB has turned out to have a good explanatory power for analyzing decision-making (Armitage \& Conner, 2000; Godin \& Kok, 1996; Hagger et al., 2002). To date, the TPB has been used successfully to understand a range of environmentally responsible behaviors such as recycling (e.g., Boldero, 1995; Cheung et al., 1999; Taylor \& Todd, 1995), composting (Taylor \& Todd, 1995), energy use (Harland et al., 1999), water conservation (Kantola et al., 1982), as well as sustainable agriculture practices (e.g. Beedell \& Rehman, 2000). Fishbein and Ajzen (2010) have kept with the Reasoned Action Approach most of the TBP elements but added additional variables: environmental constraints, actual control and skills. By doing this, they recognized that the lack of skills or certain abilities for performing the behavior can prevent action just as external factors or perception of control. The Reasoned Action Approach is significant because it assumes that design of VEPs needs to induce positive attitudes, improve either the expectations of the target populations' peers or reduce their perceived influence while improving the control perceptions of the individual. However, factors such as actual control or skills have also to be integrated in the program design and evaluation to allow for realistic design, implementation and evaluation processes.

There are significant debates how much an individual "plans" to act, with motivation and routines as significant determinants of behavior. Routines and habits have been identified in the literature to be a source of barrier to behavior change. The Theory of Interpersonal Behavior (Triandis, 1977; 1980), while being in many aspects similar to the Reasoned Action Approach, includes habit as a predictor variable of intention and behavior. Triandis (1980) suggests that situation and behavior become automatic and are partially non-conscious. On the other hand, motivation has been found to be a major determinant of behavior and motivational theories can offer some explanations regarding the origins of social cognitive beliefs (Deci \& Ryan, 1985). In the context of pro-environmental behavior, positive and negative emotions have also been found to determine action through motivational processes (Vinning \& Ebreo, 2002).

According to self-determination theory, individuals' motivation can be categorized in self-determined vs. controlled types of motivation (Deci \& Ryan, 2000). In this sense, individuals who perceive their actions to be self-determined and as a personal choice will have intrinsic motivation to act pro-environmentally. On the opposite, those individuals whose motivations are not self-determined will act only because of control and pressure. In the context of VEP adoption this aspect is crucial, since self-determination is positively correlated with behavioral engagement (Chatzisarantis et al., 2003)and can be either promoted or hindered by environmental factors (Hagger et al., 2002). Hence, VEPs which are targeted at behavioral change will have to take the question into account how to promote self-determined behavior change. Since VEP adoption decisions are either made by managers or management teams or project managers in project-based markets such as construction, interpersonal and inter-professional aspects also need to be taken into account. This transition from individual decisions and behavior to interpersonal relations leads to next higher level of analysis: the organization, groups and social networks. 


\subsection{Pro-environmental Decision Making and Behavior: Organizations, Groups and Social Networks}

Perrow (1997) describes organizations as "the most intensive and effective environmental destroyer." In addition to individual factors, research has suggested that organizational factors (i.e. organizational culture, capability to influence the strategy, long-term orientation, organizational structure, formation of environmental teams) have a substantial impact on decision-making and subsequent behavior (Nilsson et al., 2004). Certain elements are important to understanding the influence of organizations environmental behavior and decisions. One of the key issues still to be solved is whether personal priorities among decision-makers or organizational mechanisms are the most influential determinants of decisions and behavior related to pro-environmental behavior. This is also the case for the VEP design process in which the right level of intervention is of high importance. While there are an abundant number of theories on organizational behavior, models specifically related to environmental issues are rare. VEP adoption is different in many ways from the adaptation of new practices in organizations, since the decisions to work with these schemes are made at the managerial level. While some of these decisions bear consequences for the individuals within organizations, their decisions are generally less important for VEP adoption (Lutzenhiser et al., 2003). However, some theories that have their origin on the individual level of analysis can be applied to higher order units such as organizational or group behavior. Social identity theory (Tajfel \& Turner, 1979), for instance, postulates that individual behavior is a reflection of larger societal phenomena. Groups and organizations as well as the individuals' identification with them will guide internal processes and subsequently shape behavior. Social identity theory postulates that social cognitions are formed partially on group affiliation and can contribute to explain intergroup relations. Hence, a positive self-concept is derived largely from group identification and comparison between in-group and out-group (Operario \& Fiske, 1999). In the context of VEP adoption, this theoretical framework suggests that the success of adoption of a scheme is dependent not only by individual motivation but also on conflicts between groups or organizations. In that sense, decision-makers in firms will be influenced in their adoption decision by peers and what they perceive to be their peers. Conflicts between groups can contribute to a delay in uptake or make the scheme unsuccessful altogether.

The social context of environmental behaviors has been repeatedly stressed in the literature. Olli et al. (2001) suggest that network participation is an additional factor influencing pro-environmental decisions. In a professional context managers are likely to learn from their peers and the experiences of other decision-makers. Individual behaviors cumulate to social systems that will affect the social perceptions under study (Robins and Kashima, 2008). In this line of reasoning, the individual-centered social cognition research tradition can and should be complemented with social network approaches taking into account the more structural dimensions of behavior and decisions. Social network theories and analysis predicts that the more connected a decision-maker is to social network in which VEP adoption is the rule, the more likely a CEO or manager will be to adopt a VEP (Jaeger et al., 1993). Social cognition has been acknowledged to be influenced by social networks (Robins \& Kashima, 2008) and the influence of peers is likely to depend on an individual's resistance self-efficacy and the self-efficacy to "build, maintain and mobilize social networks" (Conner \& Norman, 2005; Jessor, 1998). Individual psychological differences have been found to influence networks structures; hence, even if adopting a network perspective on VEP programs, knowledge on individual differences in cognition will facilitate targeting and changing behaviors of network actors. These issues have been also addressed in theoretical models from the technology and innovation acceptance literatures.

\section{Literature on Acceptance, Adoption and Diffusion of Technology and Innovations}

The role of technology in environmental and climate change research has been strongly emphasized. Indeed, technology has often been praised in a process that Gifford (2008) has called "techno-salvation". Despite these praises, technology is not in all cases a favorable solution. The development of new environmental technology does hardly guarantee that it will be accepted or used and might in some circumstances reinforce the problems it has been thought to solve (Midden et al., 2007). The adoption of new practices and behavior change has been widely discussed in another stream of literature based on models from social psychology: studies on the adoption, acceptance and diffusion of innovations and technology. VEPs can be seen as innovations, since they are frequently related to the promotion of technological novelties such as building materials, industrial environmental management practices, or energy control mechanisms. According to Zaltman and Lin (1971), Innovations "any idea, practice, or material 92rtifact perceived to be new to the relevant adopting unit "with Adoption being "the acceptance and continued use of a product, service, or idea. The adoption process refers to a series of mental and behavioral states that a person passes through leading to the adoption or rejection of an innovation" while diffusion "is the spread of an innovation throughout a social system" (Howard \& Moore, 1982). For a detailed discussion on research streams within the literature on innovation and technology diffusion, 
acceptance and adoption, Wejnert (2002) has proposed a conceptual framework that contributes to understanding the diffusion of innovations such as the characteristics of innovations, the characteristics of innovators and the environmental context of the decision. In addition, Gopalakrishnan and Damanpour (1997), Gallivan (2001) and MacVaugh and Schiavone (2010) provide an overview on the vast diffusion of innovation and technology acceptance literature.

\subsection{Acceptance, Adoption and Diffusion of Technology and Innovations: Individual Decision Theories}

Within the study of innovation diffusion, several cognition models are well suited for the development and evaluation of VEPs. Surprisingly, models on technology and innovation acceptance models have been rarely applied to environmental decision and behavior problems even though many VEPs are targeted at eco-innovations and environmental technology promotion.

One of the predominant frameworks regarding the adoption of innovations is the Technology Acceptance Model (TAM) by Davis et al. (1989) and Bagozzi et al. (1992). Its extensions are the Technology Acceptance Model 2 (TAM2) by Venkatesh and Davis (2000) and the TAM 3 (Venkatesh \& Bala, 2008). Based on the Theory of Reasoned Action by Ajzen and Fishbein (1985) these models also include Perceived Usefulness (PU) and Perceived Ease of Use (PEU) which determine the intention and actual system usage. Even though the TAM has become one of the most popular models in this field, Bagozzi (2007) has pointed out some issues such as a neglect of the use-to-goal-attainment gap, i.e. the fact that the adoption is not the final step of the decision chain but only a medium stage to a later goal (i.e. adopting a VEP could only be the first step in a larger chain of decisions for a decision-maker). Since both the Theory of Planned Behavior and the Technology Acceptance models include the attitude concept as a determinant of behavioral intention, several authors have focused on integrating both approaches in one model by refining the attitudinal approach into Perceived Usefulness (PU) and Perceived Ease of Use (PEU) constructs (Jacoby \& Kaplan, 1972; Mathieson, 1991; Szajna, 1995; Taylor \& Todd, 1995).

Driven by criticism of the diversity of models in this field, Venkatesh et al. (2001) developed a Unified Theory of Acceptance and Use of Technology (UTAUT). This comprehensive model includes the Theory of Reasoned Action, the Technology Acceptance Model, the Motivational Model, the Theory of Planned Behavior, a Combined Theory of Planned Behavior/Technology Acceptance Model, the Model of PC Utilization, the Innovation Diffusion Theory, and Social Cognitive Theory. According to this model, performance expectancy, effort expectancy, facilitating conditions and influence determine adoption intention and behavior directly. Other relationships are mediated by gender, age, experience and voluntariness of use (Venkatesh et al., 2003). Bagozzi (2007) has pointed out the shortfalls of a model with " 41 independent variables for predicting intentions and at least eight independent variables for predicting behavior". The complexity of the model and that it is mostly interested in explaining IT adoption mechanisms limit its use significantly. Therefore, this is a case which shows that very complex behavioral models encounter limitations when used as the basis for VEP design and evaluation. Even though simplicity has led to program failures, over-complexity of models can also lead to confusion and inappropriate program development.

\subsection{Acceptance, Adoption and Diffusion of Technology and Innovations: Organizations, Groups and Networks}

In addition to the individual level, the literature on innovation adoption has a distinct organizational dimension. One of the theories linking the individual and the organizational level, and one of the most predominant to date is the Diffusion of Innovation Theory (DOI) by Rogers (2003). According to this framework, adoption of innovations in a society follows a distinct process, notably "the communication of an innovation over time through certain channels among a social system". Rogers (2003), suggests five distinct adopter categories; these groups are linked to the propensity of adopting innovations. According to the theory, network characteristics as well as the attributes of the innovation will determine on the adoption level (Rogers, 2003). An important framework less prominent in social cognition research applied to the adoption of an innovation or technology is the social network perspective. Similar to pro-environmental behavior, innovation and technology adoption has been found in some studies to accelerate the more of an individuals' peers adopt a specific innovation or technology. The "Innovation-Decision Process" describes the adoption as "knowledge of the idea", "persuasion", "decision", "information" and "confirmation" (Rogers, 2003).

The underlying assumption of DOI is that adoption processes are deliberative and social interaction determines awareness. Even though Rogers (2003) describes the adoption process as a mechanistic process, he focuses on the role of individuals and networks as well as the interaction between these levels.

According to Gallivan (2001), evidence from the technology sector suggests that frameworks focusing on individual decisions and behavior frequently neglect the organizational dimension since decisions are frequently 
made at the organizational or team level. His criticism touches upon the question whether traditional frameworks are suitable to analyze adoption processes since individual autonomy might not be present in these contexts. However, some VEP adoption processes constitute "contingent authority innovation decisions" (Zaltman et al., 1973), i.e. situations in which an organizational authority makes the initial decision to adopt and organizational members have no choice than to follow along. Since VEPs are so diverse in nature, however, no general conclusion can be made in this regard; research on these schemes has to take these issues into account on a case-to-case basis. Most of the theoretical models reviewed in the sections above can be useful in order to design effective VEPs and similar programs.

\section{Limitations}

While behavior change has been quoted as a major goal of policies and programs, the issue is whether this objective is possible and desirable. Fischhoff (1990) noted that behavior change methods are mainly appealed to when the public's behavior threatens policy-makers goals. Insights on decisions and behaviors can also be used to fortify power structures, overcoming resistance and legitimizing business and policy initiatives. While theory-based programs take the mechanisms into account by which behavior is changed, there are limitations to using social cognition theories as a basis for VEP design and evaluation. Theories may not match a specific program since high degrees of abstraction found in some models may be difficult to be operationalized in practice. The behavioral assumptions underlying each model need to be properly understood to really advance program design and evaluation in a structured manner. In some cases, several theories may need to be included in the program design. However, the more theories need to be tracked, the more expensive the evaluation (Weiss, 2000). As stated in the PRECEDE/ PROCEED (Green \& Kreuter, 1999) and the Intervention Mapping approach (Bartholomew et al., 2005), the choice of models and their combination to understand and improve VEP adoption can be difficult. Hence, a very structured approach and analysis of the problem at hand is required. Additionally, it is crucial to select a level of analysis and behavior change intervention likely to be most successful for VEP adoptions. In firms, analyzing employees' choice or preferences for a VEP are futile if the managers or CEO have decided not to adopt. Since certain factors such as technology, economy, demography, institutions and culture influence behavior and given the complexity of pro-environmental behavior and the numerous variables to be taken into account, many models are likely to be limited (Blake, 1999). Over-simplified models can be problematic when key variables missing in the model influence decision-making processes (Jackson, 2005). However, if models become too complex with a large number of variables and relationships, it gets more difficult to establish significant correlations or to detect influences on choice. Another limitation is of more theoretical than empirical concern. Since some VEPs might not be appropriate to tackle environmental issues in the first place, it needs to be thoroughly evaluated whether promoting a specific program does make sense. Based on some of the models suggested in this article, the foundations can be set to analyze environmental programs and subsequently design intervention programs in order to improve VEP adoption; this does not mean, however, to view every VEP as a beneficial scheme whose uptake needs to be improved.

In VEP design, the channels of communication are a decisive factor. To change behavior, values and beliefs have to be changed first. Attitudes per se are not good predictors of behavior, since both intrinsic and extrinsic motivations are decisive. Interpersonal communication contributes to persuasion but characteristics of audience, communicator, message and medium are decisive factors in the context of program design since individuals have existing attitudes and "latitudes of acceptance", a range of messages that can be accepted from their point of view (Thorngate, 2001).

\section{Conclusion}

In this article we have touched upon number of points in the design and analysis of Voluntary Environmental Programs that have not been mentioned in the existent literature so far. A major issue is the embeddedness of environmental and energy programs in the PTEM paradigm resulting in a reduced understanding of the adoption process, the so-called "black box" in the evaluation literature. We argue that effective programs need to be grounded in theories that allow for coherent evaluation and reliable results. Hence, program designers and evaluators need to include behavior change components in all VEPs and not only those explicitly designed for behavior change. Other fields of inquiry such as health promotion and evaluation have a longstanding tradition of applying frameworks which not only include contextual factors and policy elements but also behavioral aspects of program adoption. Hence, we have turned the health promotion literature, a field of research grounded in theory-based interventions and program planning to identify models influential in program analysis. Some of these models have already been applied to the pro-environmental behavior literature. For the behavioral analysis part of this model, the behavioral assessment and evaluation stages, we presented models from the social psychology and technology acceptance literature which contribute to an improved theory-based understanding of 
the adoption process. We suggested that embedding theories to understand and change behavioral factors in frameworks such as Intervention Mapping (Bartholomew et al., 2005) and PRECEDE/PROCEED (Green \& Kreuter, 2005) are very useful for both design and analysis of VEPs. The aim was to propose directions for studying the underlying foundations of VEP adoption that can also serve as the basis for future intervention studies aimed at improving the uptake of specific Voluntary Environmental Programs. This review does not, however, suggest that the models proposed are the only ones that have the potential to contribute to the understanding of all VEPs neither does it suggest that all the models should be applied to a specific kind of VEP. Before applying a behavioral model to a decision problem, the background, the targets, the intended results and the usefulness of a Voluntary Environmental Program has to be well understood.

\section{References}

Ajzen, I. (1991). The theory of planned behavior. Organizational behavior and human decision processes. 50 (2), 179-211. http://dx.doi.org/10.1016/0749-5978(91)90020-T

Ajzen, I. (2002). Perceived Behavioral Control, Self-Efficacy, Locus of Control and the Theory of Planned Behavior. Journal of Applied Social Psychology. 32 (4), 665-683. http://dx.doi.org/ 10.1111/j.1559-1816.2002.tb00236.x

Ajzen, I., Fishbein, M. \& Heilbroner, R. L. (1980). Understanding attitudes and predicting social behavior. (Vol. 278). Prentice-Hall Englewood Cliffs, NJ.

Ajzen, I. \& Madden, T. J. (1986). Prediction of goal-directed behavior: Attitudes, intentions, and perceived behavioral control. Journal of experimental social psychology. 22 (5), 453-474. http://dx.doi.org/10.1016/0022-1031(86)90045-4

Allport, A. (1985). The historical background of social psychology. In G. Lindzey \& E. Aronson (Eds.). Handbook of social psychology. (Vol. 1, 3rd ed., pp. 1-46). New York: Random House.

Aragón-Correa, J. A., Matías-Reche, F. \& Senise-Barrio, M.E. (2004). Managerial discretion and corporate commitment to the natural environment. Journal of Business Research. 57 (9), 964-975. http://dx.doi.org/10.1016/S0148-2963(02)00500-3

Armitage, Christopher J. \& Conner, M. (2000). Social cognition models and health behavior: A structured review. Psychology \& Health. 15 (2), 173 - 189. http://dx.doi.org/10.1080/08870440008400299

Arora, S. \& Cason, T. N. (1995). An Experiment in Voluntary Environmental Regulation: Participation in EPA's 33/50 Program. Journal of Environmental Economics and Management. 28 (3), 271-286. http://dx.doi.org/10.1006/jeem.1995.1018

Astbury, B. \& Leeuw, F. (2010). Unpacking black boxes: mechanisms and theory-building in evaluation. American Journal of Evaluation. 31 (3), 363-381. http://dx.doi.org/10.1177/1098214010371972

Bagozzi, R. P. (2007). The legacy of the technology acceptance model and a proposal for a paradigm shift. Journal of the Association for Information Systems. 8 (4), 244-254. [Online] Available: http://aisel.aisnet.org/jais/vol8/iss4/12

Bagozzi, R. P., Davis, F. D. \& Warshaw, P. R. (1992). Development and Test of a Theory of Technological Learning and Usage. Human Relations. 45 (7), 659-686. http://dx.doi.org/10.1177/001872679204500702

Bandura, A. (1985). Social foundations of thought and action: A social cognitive theory. Prentice Hall.

Banerjee, S. B. (2001). Managerial environmental attitudes and corporate environmentalism: A preliminary investigation. Journal of Environmental Education. 32 (4), 49-50. http://dx.doi.org/10.1080/00958960109598663

Banerjee, S. B. (2002). Corporate environmentalism: the construct and its measurement. Journal of Business Research. 55 (3), 177-191. http://dx.doi.org/10.1016/S0148-2963(00)00135-1

Bartholomew, L. K., Parcel, G. S., Kok, G. \& Gottlieb, N. H. (2011). Planning Health Promotion Programs: An Intervention Mapping Approach. San Francisco, CA.: Jossey-Bass.

Beedell, J. \& Rehman, T. (2000). Using social-psychology models to understand farmers' conservation behavior. Journal of Rural Studies. 16 (1), 117-127. http://dx.doi.org/10.1016/S0743-0167(99)00043-1

Blake, J. (1999). Overcoming the 'value-action gap' in environmental policy: tensions between national policy and local experience. Local Environment. 4 (3), 257-278.

Boerkey, P. \& Leveque, F. (1998). Voluntary Approaches for Environmental Protection in the European Union. Paris: OECD. 
Boldero, J. (1995). The prediction of household recycling of newspapers: The role of attitudes, intentions, and situational factors. Journal of Applied Social Psychology. 25 (5), 440-462. http://dx.doi.org/10.1111/j.1559-1816.1995.tb01598.x

Branzei, O., Ursacki-Bryant, T. J., Vertinsky, I. \& Weijiong Z. (2004). The formation of green strategies in Chinese firms: matching corporate environmental responses and individual principles. Strategic Management Journal. 25 (11), 1075-1095. http://dx.doi.org/10.1002/smj.409

Carmin, J., Darnall, N. \& Mil-Homens, J. (2003). Stakeholder Involvement in the Design of U.S. Voluntary Environmental Programs: Does Sponsorship Matter? Policy Studies Journal. 31 (4):527-543. http://dx.doi.org/10.1111/1541-0072.00041

Chatzisarantis, N. L., Hagger, M. S., Biddle, S. J. H., Smith, B. \& Wang, J. C. K. (2003). A meta-analysis of perceived locus of causality in exercise, sport, and physical education contexts. Journal of Sport and Exercise Psychology. 25, 284-306.

Cheung, S. F., Chan, D. K. S. \& Wong, Z. S. Y. (1999). Reexamining the theory of planned behavior in understanding wastepaper recycling. Environment and Behavior. $31 \quad$ (5), 587. http://dx.doi.org/10.1177/00139169921972254

Clark, C. F., Kotchen, M. J. \& Moore, M. R. (2003). Internal and external influences on pro-environmental behavior: Participation in a green electricity program. Journal of Environmental Psychology 23 (3), 237-246. http://dx.doi.org/10.1016/S0272-4944(02)00105-6

Conner, M. \& Norman, P. (Eds.). 2005. Predicting health behavior. Buckingham: Open University Press.

Cordano, M. \& Frieze I. H. (2000). Pollution Reduction Preferences of U.S. Environmental Managers: Applying Ajzen's Theory of Planned Behavior. The Academy of Management Journal. 43 (4), 627-641. [Online] Available: http://www.jstor.org/stable/1556358

Daamen, D. D. L., Staats, H., Wilke, H. A. M. \& Engelen, M. (2001). Improving environmental behavior in companies. Environment and Behavior. 33 (2), 229. http://dx.doi.org/10.1177/00139160121972963

Dahlstrand, U. \& Biel, A. (1997). Pro-Environmental Habits: Propensity Levels in Behavioral Change. Journal of Applied Social Psychology. 27 (7), 588-601. http://dx.doi.org/10.1111/j.1559-1816.1997.tb00650.x

Darnall, N. \& Edwards, D. (2006). Predicting the cost of environmental management system adoption: the role of capabilities, resources and ownership structure. Strategic Management Journal. 27 (4), 301-320. http://dx.doi.org/10.1002/smj.518

Darnall, N., Potoski, M. \& Prakash, A (2010). Sponsorship Matters: Assessing Business Participation in Government and Industry-Sponsored Voluntary Environmental Programs. Journal of Public Administration Research and Theory. 20 (2), 283-307. http://dx.doi.org/10.1093/jopart/mup014

Davis, F. D. (1989). Perceived usefulness, perceived ease of use, and user acceptance of information technology. MIS quarterly. 13 (3), 319-340. [Online] Available: http://www.jstor.org/stable/249008

Davis, F. D., Bagozzi, R. P. \& Warshaw, P. R. (1989). User acceptance of computer technology: a comparison of two theoretical models. Management science. 35 (8), 982-1003. [Online] Available: http://www.jstor.org/stable/2632151

Davis, F. D., Bagozzi, R. P. \& Warshaw, P. R. (1992). Extrinsic and intrinsic motivation to use computers in the workplace. Journal of Applied Social Psychology. 22 (14), 1111-1132. http://dx.doi.org/10.1111/j.1559-1816.1992.tb00945.x

Deci, E. L. \& Ryan, R. M. (1985). Intrinsic motivation and self-determination in human behavior. New York: Plenum.

Deci E. L. \& Ryan R. M. (2000). The "what" and "why" of goal pursuits: human needs and the self-determination of behavior. Psychol. Inq. 11 (4), 227-268. http://dx.doi.org/10.1207/S15327965PLI1104_01

Durán, M., Alzate, M., López, W. \& Sabucedo, J. M. (2007). Emotions and pro-environmental behavior. Revista Latinoamericana de Psicología. 39, 287-296.

Eden, S. E. (1993). Individual environmental responsibility and its role in public environmentalism. Environment and Planning. A25, 1743-1743. http://dx.doi.org/10.1068/a251743

Egmond C., Jonkers, R. \& Kok, G. (2005). A strategy to encourage housing associations to invest in energy conservation. Energy Policy. 33, 2374-2384. http://dx.doi.org/10.1016/j.enpol.2004.05.007 
Eriksson, L, Garvill, J. \& Nordlund. A. M. (2008). Acceptability of single and combined transport policy measures: The importance of environmental and policy specific beliefs. Transportation Research Part A: Policy and Practice. 42 (8), 1117-1128. http://dx.doi.org/10.1016/j.tra.2008.03.006

Fischhoff, B. 1990. Psychology and public policy: Tool or toolmaker? American. Psychologist. 45:647-653.

Fischhoff, B, Bostrom A. \& Quadrel M. J. (1997). Risk perception and communication. In Oxford Textbook of Public Health, ed. R Detels, W Holland, J McEwen, GS Omenn. (pp. 987-1002). Oxford, UK: Oxford Univ. Press.

Fishbein, M. \& Ajzen, I. (1975). Belief, attitude, intention and behavior: An introduction to theory and research. Reading, MA: Addison-Wesley.

Fishbein, M. \& Ajzen, I. (2010). Predicting and changing behavior: The reasoned action approach: Psychology Press New York.

Fitz-Gibbon, C. T. \& Morris, L. L. (1996). Theory-based evaluation. Evaluation Practice. 17 (2),177-184. http://dx.doi.org/10.1016/S0886-1633(96)90024-0

Gallivan, M. J. (2001) Organizational adoption and assimilation of complex technological innovations: development and application of a new framework. ACM Sigmis Database. 32 (3), 51-85. http://dx.doi.org/10.1145/506724.506729

Gifford, R. (2008). Psychology's essential role in alleviating the impacts of climate change. Canadian Psychology. 49, 273-280. http://dx.doi.org/10.1037/a0013234

Godin, G. \& Kok, G. (1996). The theory of planned behavior: a review of its applications to health-related behaviors. American journal of health promotion: AJHP. 11 (2), 87.

Gopalakrishnan, F. (1997). A review of innovation research in economics, sociology and technology management. Omega. 25 (1), 15-28. http://dx.doi.org/10.1016/S0305-0483(96)00043-6

Gough, A. (2002). Mutualism: a different agenda for environmental and science education. International Journal of Science Education. 24 (11), 1201-1215.

Green, L. W. \& Kreuter, M. W. (1999). Health Promotion Planning: An Educational and Ecological Approach. third edition ed. Mountain View (California): Mayfield Publishing Company.

Guagnano, G. A., Stern, P. C. \& Dietz, T. 1995. Influences on Attitude-Behavior Relationships. Environment and Behavior. 27 (5), 699-718. http://dx.doi.org/10.1177/0013916595275005

Gunningham, N. \& Sinclair, D. (1999). Integrative Regulation: A Principle-Based Approach to Environmental Policy. Law \& Social Inquiry. 24 (4), 853-896. http://dx.doi.org/10.1111/j.1747-4469.1999.tb00407.x

Hagger, M. S, Chatzisarantis, N. L. D. \& Biddle, S. J. H. (2002). A meta-analytic review of the theories of reasoned action and planned behavior in physical activity: Predictive validity and the contribution of additional variables. Journal of Sport \& Exercise Psychology. 24 (1), 3-32.

Harland, P., Staats, H. \& Wilke, H. A. M. (1999). Explaining Pro-environmental Intention and Behavior by Personal Norms and the Theory of Planned Behavior. Journal of Applied Social Psychology. 29 (12), 2505-2528. http://dx.doi.org/10.1111/j.1559-1816.1999.tb00123.x

Harrison, D. A. (1995). Volunteer motivation and attendance decisions: Competitive theory testing in multiple samples from a homeless shelter. Journal of Applied Psychology. 80, 371-385. http://dx.doi.org/10.1037/0021-9010.80.3.371

Heimlich, J. E. \& Ardoin, N. E. (2008). Understanding behavior to understand behavior change: a literature review. Environmental Education Research. 14 (3), 215-237. http://dx.doi.org/10.1080/13504620802148881

Hines, J. M., Hungerford, H. R. \& Tomera, A. N. (1987). Analysis and synthesis of research on responsible environmental behavior: Ameta-analysis. Journal of Environmental Education. 18, 1-18.

Hoffman, A. J. (2001). Linking Organizational and Field-Level Analyses. Organization \& Environment1. 4 (2), 133-156. http://dx.doi.org/10.1177/1086026601142001

Howard, J. A. \& Moore, W. L. (1982). Changes in consumer behavior over the product life cycle. In Readings in the management of innovation, edited by M. L. Tushman. Cambridge, MA: Ballinger.

Jackson, T. (2005). Motivating Sustainable Consumption: a review of evidence on consumer behavior and behavioral change. London: Policy Studies Institute. 
Jacoby, J. \& Kaplan, L. M. (1972). The components of perceived risk.Proceeding ACR (pp. 382-393).

Jaeger, C., Durrenberger, G., Kastenholz, H. \& Truffer, B. (1993). Determinants of environmentalaction with regard to climatic change. Climatic Change. 23 (3), 193-211. http://dx.doi.org/10.1007/BF01091615

Jessor, R (1998). New Perspectives on Adolescent Risk Behavior. New York: Cambridge University Press.

Kahn, M. E. (2002). Demographic change and the demand for environmental regulation. Journal of Policy Analysis and Management. 21 (1), 45-62. http://dx.doi.org/10.1002/pam.1039

Kaiser, F. G., Hübner,G. \& Bogner, F. X. (2005). Contrasting the Theory of Planned Behavior With the Value Belief Norm Model in Explaining Conservation Behavior. Journal of Applied Social Psychology. 35 (10), 2150-2170. http://dx.doi.org/10.1111/j.1559-1816.2005.tb02213.x

Kantola, S. J, Syme, G. J. \& Campbell, N. A. (1982). The role of individual differences and external variables in a test of the sufficiency of Fishbein's model to explain behavioral intentions to conserve water. Journal of Applied Social Psychology. 12 (1), 70-83. http://dx.doi.org/10.1111/j.1559-1816.1982.tb00850.x

Khanna, M., Quimio W. R. H. \& Bojilova, D (1998). Toxics Release Information: A Policy Tool for Environmental Protection. Journal of Environmental Economics and Management. 36 (3), 243-266. http://dx.doi.org/10.1006/jeem.1998.1048

Khanna, M., Koss, P., Jones, C. \& Ervin, D. (2007). Motivations for Voluntary Environmental Management. Policy Studies Journal. 35 (4), 751-772. http://dx.doi.org/10.1111/j.1541-0072.2007.00246.x

Khanna, M. \& Damon, L. (1999). EPA's Voluntary 33/50 Program: Impact on Toxic Releases and Economic Performance of Firms. Journal of Environmental Economics and Management. 37 (1), 1-25. http://dx.doi.org/10.1006/jeem.1998.1057

Kok, G, Schaalma, H., Ruiter, R., Empelen, P van \& Brug J. (2004). Intervention mapping: A protocol for applying Health Psychol theory to prevention programmes. Journal of Health Psychology. 9, 85-89. http://dx.doi.org/10.1177/1359105304038379

Langlois, M. A. \& Hallam, J. S. (2010). Integrating Multiple Health Behavior Theories Into Program Planning: The PER Worksheet. Health Promotion Practice11. (2), 282-288. http://dx.doi.org/10.1177/1524839908317668

Laroche, M., Toffoli, R., Kim, C. \& Muller, T. E. (1996). The Influence of Culture on Pro-Environmental Knowledge, Attitudes, and Behavior: A Canadian Perspective. Advances in Consumer Research. 23, 196-202. [Online] Available: http://www.acrwebsite.org/volumes/display.asp?id=7942

Lewin, K. (1951). Field theory in social science: selected theoretical papers Edited by D. Cartwright. New York: Haper and Row.

Lippke, S. \& Ziegelmann, J. P. (2008). Theory-Based Health Behavior Change: Developing, Testing, and Applying Theories for Evidence-Based Interventions. Applied Psychology: International Review. 57, 698-716. http://dx.doi.org/10.1111/j.1464-0597.2008.00339.x

Lutzenhiser, L. (2009). The Evolution of Electricity Efficiency Policy, the Importance of Behavior and Implications for Climate Change Intervention. In Perspectives on EnergyPolicy, edited by D. Reeve and M. Stabile. Toronto, Canada: University of Toronto Press.

MacVaugh, J. \& Schiavone, F. (2010). Limits to the diffusion of innovation: A literature review and integrative model. European Journal of Innovation Management1. 3 (2), 197-221. http://dx.doi.org/10.1108/14601061011040258

Martín-Peña, M. L., Díaz-Garrido, E. \& Sánchez-López, J. M. (2010). Relation between management's behavioral intentions towards the environment and environmental actions. Journal of Environmental Planning and Management. 53 (3), 297 - 315. http://dx.doi.org/10.1080/09640561003612866

Mathieson, K. (1991). Predicting user intentions: comparing the technology acceptance model with the theory of planned behavior. Information systems research. 2 (3), 173-191. http://dx.doi.org/10.1287/isre.2.3.173

Michie, S., Johnston, M., Francis, J., Hardeman, W. \& Eccles, M. (2008). From Theory to Intervention: Mapping Theoretically Derived Behavioral Determinants to Behavior Change Techniques. Applied Psychology:An international review. 57(4), 660-680.

Nilsson, A. \& Biel. A. (2008.) Acceptance of climate change policy measures: role framing and value guidance. European Environment1. 8 (4), 203-215. http://dx.doi.org/10.1002/eet.477

Nilsson, A., von Borgstede, C. \& Biel, A. (2004). Willingness to accept climate change strategies: The effect of 
values and norms. Journal of Environmental Psychology. 24, 267-277. http://dx.doi.org/10.1016/j.jenvp.2004.06.002

Nordlund, A. M. \& Garvill, J. (2002). Value structures behind pro-environmental behavior. Environment and Behavior. 34 (6), 740. http://dx.doi.org/10.1177/001391602237244

Olli, E., Grendstad, G. \& Wollebaek, D. (2001). Correlates of environmental behaviors: Bringing back social context. Environment and Behavior. 33 (2), 181-208. http://dx.doi.org/10.1177/0013916501332002

Operario, D. \& Fiske, S. T. (1999). Social cognition permeates social psychology: Motivated mental processes guide the study of human social behavior. Asian Journal of Social Psychology. 2, 63-78. http://dx.doi.org/10.1111/1467-839X.00026

Pawson, R. \& Tilley, N. (1997). Realistic Evaluation. London: Sage.

Perrow, C. (1997). Organizing for environmental destruction. Organization \& Environment. 10 (1), 66. http://dx.doi.org/10.1177/0921810697101009

Robins, G. \& Kashima, Y. (2008). Social psychology and social networks. Asian Journal of Social Psychology. 11 (1), 1-12. http://dx.doi.org/10.1111/j.1467-839X.2007.00240.x

Rogers, E.M. (2003). Diffusion of Innovations. New York: Free Press.

Schlange, L. E. (2009). Stakeholder Identification in Sustainability Entrepreneurship:The Role of Managerial and Organisational Cognition. Greener Management International. 55, 13-55.

Schwartz, S. H. (1977). Normative Influences on Altruism. In Advances in Experimental Social Psychology, (ed) B. Leonard: Academic Press.

Schwartz, S. H. (1992). Universals in the Content and Structure of Values: Theoretical Advances and Empirical Tests in 20 Countries. In Advances in Experimental Social Psychology, edited by P. Z. Mark: Academic Press.

Sharma, S. (2000). Managerial interpretations and organizational context as predictors of corporate choice of environmental strategy.Academy of. Management Journal. 43, 681-697. [Online] Available: http://www.jstor.org/stable/1556361

Smith E. R. \& Semin G. R. (2004). Socially situated cognition: cognition in its social context. Advances in .Experimental Social Psychology. 36, 53-117. http://dx.doi.org/10.1016/S0065-2601(04)36002-8

Stame, N. (2004b). Theory-Based Evaluations and Types of Complexity, Evaluation. 10 (1), 58-76. http://dx.doi.org/10.1177/1356389004043135

Steelman, T. A. \& Rivera, J. (2006). Voluntary Environmental Programs in the United States. Organization \& Environment. 19 (4), 505-526. http://dx.doi.org/10.1177/1086026606296393

Steg, L., Lieke D. \& Abrahamse, W. (2005). Factors influencing the acceptability of energy policies: A test of VBN theory. Journal of Environmental Psychology. 25 (4), 415-425. http://dx.doi.org/10.1016/j.jenvp.2005.08.003

Stern, P. C. (2000). New Environmental Theories: Toward a Coherent Theory of Environmentally Significant Behavior. Journal of Social Issues. 56 (3), 407-424. http://dx.doi.org/10.1111/0022-4537.00175

Stern, P. C. \& Dietz, T. (1994). The value basis of environmental concern. Journal of Social Issues. 50 (3), 65-84. http://dx.doi.org/10.1111/j.1540-4560.1994.tb02420.x

Stern, P. C., Dietz, T., Abel, T., Guagnano, G. A. \& Kalof, L. (1999). A Value-Belief-Norm Theory of Support for Social Movements: The Case of Environmentalism. Human Ecology Review. 6 (2), 81-97. [Online] Available: http://ibcperu.org/doc/isis/5623.pdf

Stern, P. C. \& Oskamp, S. (1987). Managing scarce environmental resources. Handbook of environmental psychology. 2, 1043-1088.

Stewart, A. M. \& Craig, J. L. (2001). Predicting pro-environmental attitudes and behaviors: A model and a test. Journal of Environmental Systems. 28 (4), 293-317. [Online] Available: http://baywood.metapress.com/openurl.asp?genre=article\&id=doi:10.2190/JMYR-C6R4-PB2R-1K38

Syme, G. J. M., Nancarrow, B. E. \& Seligman, C. (2000). The evaluation of information campaigns to promote voluntary household water conservation. Evaluation Review. 24, 539-578. http://dx.doi.org/10.1177/0193841X0002400601

Szajna, B. (1996). Empirical evaluation of the revised technology acceptance model. Management science. 42 
(1), 85-92. [Online] Available: http://www.jstor.org/stable/2633017

Tabernero, C. \& Hernández, B. (2010). Self-efficacy and intrinsic motivation guiding environmental behaviour. Environment and Behaviour. 20 (10), 1-18. http://dx.doi.org/10.1177/0013916510379759

Tajfel, H. \& Turner, J. C. (1979). An integrative theory of intergroup conflict. In The Social Psychologyof Intergroup Relations, Ed. WG Austin, S Worchel. (pp. 33-47). Monterey, CA: Brooks/Cole.

Taylor, S. \& Todd, P. (1995). An Integrated Model of Waste Management Behavior. Environment and Behavior. 27 (5), 603-630. http://dx.doi.org/10.1177/0013916595275001

Taylor, S. \& Todd, P. (1995). Understanding information technology usage: A test of competing models. Information systems research. 6 (2), 144-176.

Thorngate, W. (2001). The social psychology of policy analysis. Journal of Comparative Policy Analysis:Research and Practice. 3, 85-112. http://dx.doi.org/10.1023/A:1011486809357

Tilikidou, I. (2007). The effects of knowledge and attitudes upon Greeks' pro-environmental purchasing behavior. Corporate Social Responsibility and Environmental Management1. 4 (3), 121-134. http://dx.doi.org/10.1002/csr.123

Triandis, H. C. (1977). Interpersonal Behavior. Monterey, C.A: Brook/Cole.

Triandis, H. C. (1980). Values,attitudes, and interpersonal behavior. In H. E. Howe \& M. M.Page (Eds.), Nebraska Symposium on Motivation 1979. (pp. 195-259). Lincoln: University of Nebraska Press.

Uzzell, D. (2007). How the science of psychology can make a contribution to sustainable development. Working Paper. British Psychological Society.

Venkatesh, V. (2006). Where To Go From Here? Thoughts on Future Directions for Research on Individual Level Technology Adoption with a Focus on Decision Making. Decision Sciences. 37 (4), 497-518.

Venkatesh, V. \& Bala, H. (2008). Technology acceptance model 3 and a research agenda on interventions. Decision Sciences. 39 (2), 273-315. http://dx.doi.org/10.1111/j.1540-5414.2006.00136.x

Venkatesh, V. \& Davis. F. D. (2000). A theoretical extension of the technology acceptance model: Four longitudinal field studies. Management science. 46 (2), 186-204. [Online] Available: http://www.jstor.org/stable/2634758

Venkatesh, V., Morris, M., Davis, G. B., Davis, F. D., DeLone, W., McLean, E., Jarvis. F., MacKenzie, S.B., Podsakoff, P. M. \& Chin, W. W. (2003). User acceptance of information technology: Toward a unified view. Information Management. 27 (3), 425-478. [Online] Available: http://www.jstor.org/stable/30036540

Vine, E. (1994). The Human Dimension of Program Evaluation, Energy - The International Journal. 19 (2), 165-178. http://dx.doi.org/10.1016/0360-5442(94)90057-4

Weick, K. E. (1996). Sensemaking in Organizations. Sage Publications, Thousand Oaks, CA.

Weick, K. Sutcliffe, K. \& Obstfeld, D. (2005). Organizing and the process of sense-making. Organizational Science1. 6(4), 409-21. [Online] Available: http://www.jstor.org/stable/25145979

Weiss, C. H. (1997). How Can Theory-Based Evaluation Make Greater Headway? Evaluation Review. 21, 501-524. http://dx.doi.org/10.1177/0193841X9702100405

Weiss, C. H. (2000). Which links in which theories shall we evaluate? New Directions in Evaluation. 87, 35-45. http://dx.doi.org/10.1002/ev.1180

Wejnert, B. (2002). Integrating Models of Diffusion of Innovations: A Conceptual Framework. Annual review of sociology. 297-327. [Online] Available: http://www.jstor.org/stable/3069244

Welch, Eric W., Mazur, A. \& Bretschneider, S. (2000). Voluntary behavior by electric utilities: Levels of adoption and contribution of the climate challenge program to the reduction of carbon dioxide. Journal of Policy Analysis and Management. 19 (3), 407-425. http://dx.doi.org/10.1002/1520-6688(200022)

Widegren, Ö. (1998). The New Environmental Paradigm and Personal Norms. Environment and Behavior. 30 (1), $75-100$.

Williams, H. E., Medhurst, J. \& Drew, K. (1993). Corporate strategies for a sustainable future.In Environmental strategies for industry. International perspectives on research needs and policy implications, edited by K. F. a. J. Schot. Washington, DC.: Island Press.

Zaltman, G, \& Lin, N. (1971). On the Nature of Innovations. American Behavioral Scientist1. 4 (5), 651-673. 
Zaltman, G., Duncan, R. \& Holbeck, J. (1973). Innovations and Organisations. New York, John Wiley \& Sons.

Table 1. Overview of different VEP schemes adapted from Carmin et al. (2003)

\begin{tabular}{|c|c|c|}
\hline Sponsor Organisation & Schemes (Examples) & Motivations for VEP design \\
\hline Governments & $\begin{array}{l}\text { Negotiated agreements (e.g. Long- } \\
\text { Term Agreements for Energy } \\
\text { Efficiency) } \\
\text { Environmental management } \\
\text { schemes } \\
\text { Standards } \\
\text { Building standards } \\
\text { Eco-labels }\end{array}$ & $\begin{array}{l}\text { decrease costs for administration } \\
\text { and enforcement } \\
\text { alternative and complement to other } \\
\text { environmental policy instruments }\end{array}$ \\
\hline Industry and Trade Organizations & $\begin{array}{l}\text { Certifications for green buildings } \\
\text { Environmental management } \\
\text { schemes } \\
\text { Professional accreditation for } \\
\text { sustainability schemes } \\
\text { Eco-labels }\end{array}$ & $\begin{array}{l}\text { increase flexibility for } \\
\text { environmental management } \\
\text { affect, avoid or delay regulations } \\
\text { create industry specific solutions }\end{array}$ \\
\hline Non-Profit Organizations & $\begin{array}{l}\text { Certifications for green building } \\
\text { Eco-labels } \\
\text { Professional accreditation for } \\
\text { sustainability schemes }\end{array}$ & $\begin{array}{l}\text { encourage environmentally friendly- } \\
\text { business practices } \\
\text { non-governmental and non-industry } \\
\text { alternatives }\end{array}$ \\
\hline International Organizations & $\begin{array}{l}\text { Eco-labels } \\
\text { Environmental management } \\
\text { schemes } \\
\text { Certifications for green buildings }\end{array}$ & $\begin{array}{l}\text { provide international guidelines } \\
\text { achieve more cooperation in } \\
\text { environmental issues }\end{array}$ \\
\hline
\end{tabular}

Table 2. Factors influencing pro-environmental decisions

\begin{tabular}{|c|c|}
\hline External factors & Internal factors \\
\hline $\begin{array}{l}\text { Institutional factors (e.g. Clark et al., } \\
\text { 2003) } \\
\text { Economic factors (e.g. Clark et al, } \\
2003 \text { ) } \\
\text { - Social and Cultural factors (e.g Laroche, } \\
\text { 1996) } \\
\text { - Demographic factors (e.g. Kahn, 2002) }\end{array}$ & $\begin{array}{ll}\text { - } & \text { Motivations (e.g. Tarbernero and } \\
\text { - } & \text { Herdandez, 2010) } \\
\text { - } & \text { Knowledge (e.g. Tilikidou, 2006) } \\
\text { - } & \text { Self- efficacy (e.g. Tarbernero and } \\
& \text { Hernandez, 2010) } \\
\text { - } & \text { Awareness (e.g.Gough, 2002) } \\
\text { - } & \text { Attitudes (e.g. Stewart, 2001) } \\
\text { - } & \text { Emotions (e.g. Duran et al., 2007) } \\
\text { - } & \text { Values (e.g Nordlund and Garvill, } \\
\text { - } & \text { Habits (e.g. Dahlstrand, 1997) } \\
\text { - } & \text { Norms (Stern et al., 1999) } \\
\text { - } & \text { Risk perception (Fischhoff et al.,1997) }\end{array}$ \\
\hline
\end{tabular}


Table 3. Selection of socio-psychological models relevant to VEP adoption

\begin{tabular}{|c|c|c|}
\hline & Individual Level & Organizational and Group Level \\
\hline Social Psychology & $\begin{array}{l}\text {-Value Belief Norm (VBN) Theory } \\
\text { (Stern et al., 1999) } \\
\text { - Attitude Behavior Context (ABC) } \\
\text { Theory (Guagnano, Stern and Dietz, } \\
\text { 1995) } \\
\text {-Reasoned Action Approach (Fishbein } \\
\text { and Ajzen, 2010) } \\
\text {-Self-Determination Theory (Deci and } \\
\text { Ryan, 2000) } \\
\text { - Theory of Interpersonal Behavior } \\
\text { (Triandis, 1977) } \\
\text {-Social identity theory (Tajfel and } \\
\text { Turner, 1979) }\end{array}$ & $\begin{array}{l}\text {-Social Identity Theory (Tajfel and } \\
\text { Turner, 1979) }\end{array}$ \\
\hline $\begin{array}{l}\text { Technology Adoption and } \\
\text { Diffusion of Innovation }\end{array}$ & $\begin{array}{l}\text {-Technology Acceptance Model } \\
\text { (TAM) (Davis et al., } 1989 \text { and } \\
\text { Bagozzi et. al, 1992) } \\
\text {-Unified Theory of Acceptance and } \\
\text { Use of Technology (UTAUT), } \\
\text { (Venkatesh et al., 2001) } \\
\text {-Decomposed model of TAM and } \\
\text { TPB (Taylor and Todd, 1995) }\end{array}$ & $\begin{array}{l}\text {-Diffusion of Innovation Theory (DOI) } \\
\text { (Rogers,2003) }\end{array}$ \\
\hline Change Theories & $\begin{array}{l}\text {-Social Cognitive Theory (Bandura, } \\
1985 \text { ) }\end{array}$ & -Change Theory (Lewin, 1955) \\
\hline
\end{tabular}

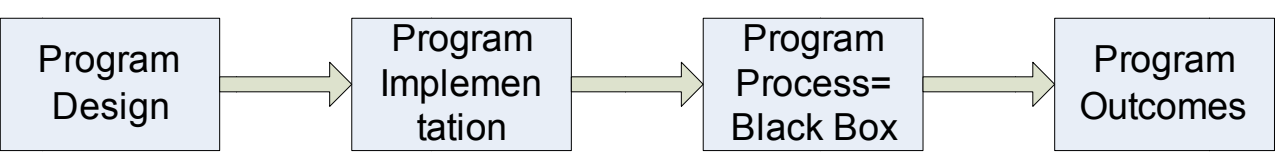

Figure 1. "Black Box" issue (Astbury and Leeuw, 2010)

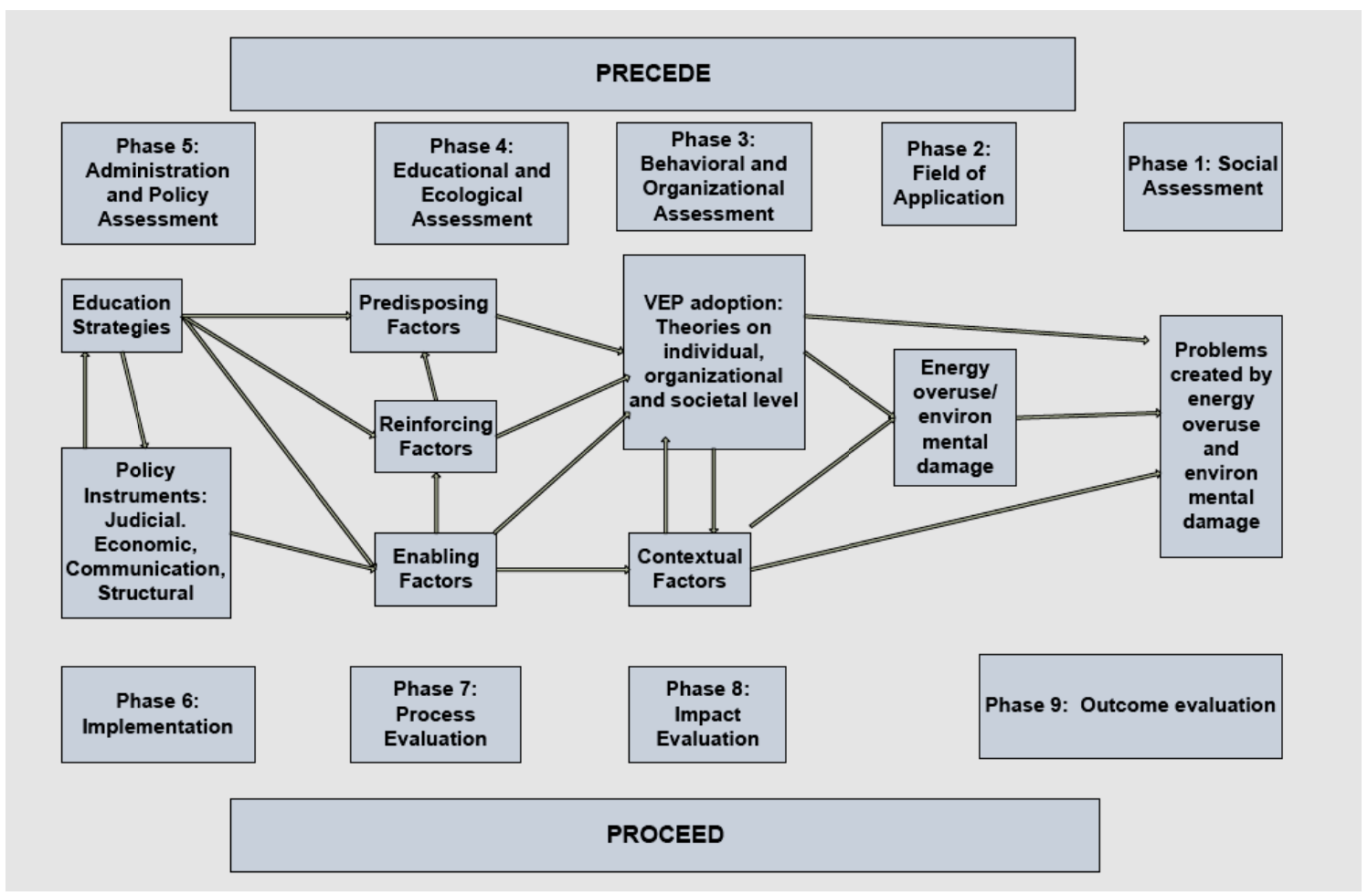

Figure 2. PRECEDE/PROCEED model by Green and Kreuter (1999) applied to VEP evaluation processes 